\title{
Discussion on the Ways for College Counselors to Improve their Guidance on Innovation and Business Startup
}

\author{
Jianbo Chen ${ }^{1, \text { a }}$, Zhi Dai ${ }^{1, b}$ \\ ${ }^{1}$ School of Materials Science and Engineering, Southwest Petroleum University, Chengdu \\ 610500, China \\ a417972609@qq.com, b25296984@qq.com
}

Keywords: College counselor, College students, Innovation and business startup education, Strategies.

Abstract: Since the launch of the concept of "mass entrepreneurship and innovation", Chinese colleges and universities have made tremendous efforts to encourage the undergraduates' education of innovation and business startup. In this process, the importance of college counselors cannot be overstated. This article discusses their functions in the education of innovation and business startup, examines the difficulties and proposes several strategies, which can provide potential reference for colleges and universities in the future innovation and business startup education.

Original article, Published date: 2018-06-19

DOI: 10.23977/aetp.2018.21003

ISSN: ISSN 2371-9397 (Print), ISSN 2371-9400 (Online)

https://www.clausiuspress.com/journal/AETP.html

\section{Introduction}

In the government work report for 2018, Chinese Premier Li Keqiang emphasized that the nationwide business startup and innovation drive was to be taken to a higher level. The government would provide all-around services for inventors and entrepreneurs to boost business startup, giving access to more job creation and employment [1]. In order to boost innovation and business startup, a 
large scale of human resources are needed [2]. Due to higher education college students receive, they are more knowledgeable and motivational, and are undoubtedly most qualified in innovation and business startup. Therefore, it is of great significance to efficiently initiate innovation and business startup education for college students, arouse their enthusiasm as well as improve their abilities. Since the innovation and business startup education at Chinese universities is relatively new and far from being universally carried out, no effective model has yet formed. And unfortunately, College counselors, mainly comprised of senior college students and postgraduate students, didn't give much stress on the innovation and business startup education, despite that they closely work with college students [3]. Therefore, the article focuses on the role of the college counselors in the innovation and business startup education of college students, providing references on improvement of innovation and business startup guidance ability.

\section{The role of college counselors in the innovation and business startup education for college}

\section{students}

As an important part of the university faculty, here is much reason to suppose that counselors are vital and indispensable for college students not only in their routines but also in their innovation and business startup education despite the current difficulties counselors are facing.

\subsection{Counselors are the main communicators and organizers of innovation and business startup education in colleges and universities}

In addition to the daily mentoring work, counselors can take advantage of the frequent contact with college students to make more direct and deeper contributions to the innovation and business startup education. The arguably most difficult part of innovation and business education is how to arouse the entrepreneurship of students, which is also a prerequisite for college students to be actively involved in innovation and business startup. Specifically, the recommended paths are as follows. First, the counselor can organize some theme class meetings and make reports to deliver the development of innovation and business startup policies under the current situation, helping students make full understand of these policies and the situation. Further, by encouraging students to integrate their personal development with our national innovation-driven development and the demands of modern society, they will better comprehend the meanings of innovation and business startup. Above all, counselors need to consciously arouse the innovative awareness and entrepreneurial ability of students. Second, counselors can foster an active atmosphere of innovation and business startup through relevant lectures and competitions. Third, with the provider of relevant training and step-by-step coaching of innovation and business startup, the students can reap great benefits, too [4].

\subsection{Counselors are leaders and instructors of innovation and business startup education in colleges and universities}

University is a critical time for a person, shaping the personality literally. College students are young and energetic, and have strong cognition and learning ability to the outside world. At the time 
while students are learning professional knowledge and improving overall qualities, counselors can consciously act as the leaders and mentors of innovation and entrepreneurship education, increase the breadth and depth of ideological and political education for college students and organically integrate ideological and political education with innovation and business startup education for college students. Counselors can use multiple ways to inspire college students' thoughts, explore their potential, and cultivate their abilities of innovation and business startup.

Because lacking relevant knowledge, experience and abilities to practice in innovation and business startup for most students, counselors are supposed to take the lead in organizing innovation and business startup activities, help them accurately learn about themselves, analyze the environment objectively, and establish scientifically goals of business startup. Counselors also must be able to give students a comprehensive system of practical guidance, such as orientation planning, experience teaching, and step guidance, connecting their growth and development with the cultivation of innovative entrepreneurship. By doing so, counselors can really help guide the students practically, and improve the innovation quality [5].

\subsection{Counselors are service providers and liaisons for innovative entrepreneurship education at colleges and universities}

Counselors should provide high-quality services referred to innovation and business startup education and practice for students, pave the way and create opportunities, and adjust mentality to eliminate obstacles in the practice of innovation and business startup. Counselors should work hard to support students, provide students with entrepreneurial policies and regulations, help students who want to start a business and apply for start-up subsidies and loans, and help prospective students develop and perfect business plans. Such as guiding students to do well in market researches, collecting business information, information about customers, products, competitors and environment are all included. Apparently, counselors want to promote the success of each entrepreneurial student. Counselors should also be good entrants in innovation and business startup education while doing a good job in innovation and business startup education services. With more contact with students and better understanding of career development plan for each student, therefore, when organizing activities, counselors can integrate all in-campus and off-campus resources to provide students with a variety of higher quality entrepreneurial education practice resources.

3. The difficulties to college counselors in innovation and entrepreneurial education for college students

\subsection{Insufficient time that can be devoted}

Due to the nature of their work, counselors need to deal with hundreds of students on a large number of tasks each day. The pressure of their own work, after the students' ideological and political education work and daily management affairs are done, makes it impossible to invest sufficient time in innovation and business startup education. If college counselors do not have 
sufficient time to systematically learn innovation and business startup, they will feel powerless in the process of guiding students.

\subsection{Lack of systematic training and learning of innovative entrepreneurship-related knowledge.}

For most counselors, there is little possibility in participating in or implementing their own business startup. The lack of cognition of innovation and business startup makes them coach and influence students with little effect. In addition, when it comes to innovation and business startup, some colleges and universities don't ever take systematic training for counselors seriously, which leads counselors do not have a good understanding of the ideas and connotations of innovation and business startup education. Ultimately, counselors cannot effectively guide the students' innovation and business startup education, and themselves are shortage of innovative entrepreneurial atmosphere creation, practical guidance, and individual tutoring.

\subsection{No significance or sufficient condition was given to the participation of counselors in the innovation and business startup education of college.}

In the process of carrying out innovation and business startup education for college students, colleges and universities often overlook the important role of counselors who have more contact with students, do not give corresponding conditions, and neglect the training and learning of counselors in innovation and business startup, resulting in the incapacity of counselors' team in guiding innovation and business startup activities. Since the achievements of business startup education, such as changes in students' interests, behaviors, attitude, and values, are often not easy to show, it is difficult to assess the effectiveness of quantitative indicators. Therefore, in view of the fact that colleges and universities have not fully affirmed and praised the input results of counselors in innovation and business startup education, a gap in the expectation of their careers is formed, reducing their willing to devote more effort in business startup education. These are the problems which are urgently needed to be solved in the process of innovation and business startup education for colleges and universities in the new era, as well as the important steps to improve the innovation and business startup education system in colleges and universities.

\subsection{Some counselor do not fully understand the meaning of innovation and business startup guidance.}

On the one hand, colleges and universities attach less importance to the participation of counselors in college students' innovation and business startup education. On the other hand, counselors themselves do not pay enough attention to business startup education. Besides, their lack of awareness of themselves, lack of time and energy are also the difficulties faced by counselors in carrying out innovation and business startup education. Not until recent years have colleges and universities begun to vigorously promote innovation and business startup. The new job asks for higher requirements for counselors. Thus, Whether the counselors pay attention to this work or not, how much the determination they have about improving their ability in guiding innovation and business startup education, how to coordinate the proportion between students' daily management 
activities and innovation and business startup education, and what can be done to combine ideological and political education with innovation and business startup education for undergraduates, each leader needs to have a reflection on his or her own education concept.

\section{Ways for counselors to improve their innovation and business startup guidance}

Although college counselors will encounter lots of issues in carrying out innovation and business startup education for college students, both colleges and counselors themselves should recognize that counselors can play a significant role in it. Hence, a platform for learning and training should be provided by colleges and universities. At the same time, full affirmation to the counselors' efforts in business startup education is also a necessity. Except for these, the counselors themselves should make reasonable arrangements for their own time, planning their own development, and actively improving the coaching ability of innovation and business startup.

\subsection{Transforming the concept of educating people and strengthening the training of counselors' awareness of innovation and business startup}

To deepen the reform of innovation and business startup education and improve the quality of education comprehensively, we must first change teachers' traditional concept of educating people. Meanwhile, the key to innovation and business startup education lies in the transformation of education concepts and culture models. As a result, if college educators want to cultivate innovative talents with innovative ideas and entrepreneurial capabilities, we need to alter the concept and methods of educating people firstly, transforming the traditional teaching style of education into heuristic education, so as to cultivate students' innovative consciousness of imagination, creativity, discovery and divergent thought. And positively carrying out entrepreneurial activities to train students' information-gather abilities, problems-solve abilities, enterprise scheme abilities, and execution abilities. Only by intensifying the counselor's awareness of innovation and business startup, and permeating it through counselors' guidance of students' learning activities, can we truly integrate innovation and business startup education into the entire process of talent cultivation. Therefore, counselors need to scientifically grasp the intrinsic relationship between innovation and business startup education and professional subject education, quality-oriented education, and employment education, adhering to the goal of promoting students' all-round development, focusing on the cultivation of students' consciousness and spirit of innovation and business startup, relying on the innovative and entrepreneurial projects and activities, and establishing the new concept of innovation and business startup education that takes the ability improvement in innovation and business startup as the core. Thus, students' knowledge, ability and quality of innovation and business startup can meet expectation.

\subsection{Improving the incentive mechanism and mobilizing the counselors to participate in the initiative of innovation and business startup education}

First, colleges and universities can incorporate innovation and business startup education into their assessment and evaluation system so that the counselors would like to attach great importance to it 
and recognize that innovation and business startup education is an important part of ideological and political education for college students and a crucial link in cultivating innovative talents. Second, they should improve incentive mechanisms about participating in innovation and business startup education for counselors, encouraging them to put more efforts in innovation and business startup work, and creating a good environment for them to launch innovation and business startup education. Third, by in favor of counselors' achievements and admiring their harvests in innovation and business startup education, their enthusiasm and initiation can be enhanced tremendously. Speaking for concrete operations, on the basis of relevant policies, the following incentive ways can effectively promote innovation and business startup education. First is to implement the innovation and entrepreneurial mentoring system, encourage teachers to lead and guide students in innovation and business startup, and reward both teachers and students performing outstandingly to set an example for others. The second is to inspire students to develop new products, hold innovation and business startup briefings, and take part in entrepreneurial practice under the guidance and support of counselors. For the pay during work, as long as beneficial to improve college students' ability of innovation and business startup, it should be listed as the curriculum of the teaching plan, the composition of teacher's workload or converted into corresponding treatment for them. Additionally, to forge iron, one must be strong, which means counselors themselves are supposed to learn more and enhance the ability level of innovation and business startup guidance.

\subsection{Attention should be paid to the training of counselors to build the related innovation and business startup knowledge learning platform}

In the daily management of students' work, it is certainly true that the counselors are expected to integrate the concepts of innovation and business startup, subconsciously affect the students' awareness of innovation and business startup and professional accomplishment, through which the full coverage of innovation and business startup education can be reached. In return, colleges and universities must attach importance to the quality training of the counselors themselves and build a knowledge learning platform for innovation and business startup. On the one hand, colleges and universities pave the way for counselors to participate in innovation and business startup training, provide relevant learning platform, and regularly organize training in theoretical knowledge about innovation and business startup education, during the process of which consciously cultivating the counselors' ability of guidance about innovation and business startup, and helping them accumulate related experience, timely grasp national innovation and business startup policies, literally master theoretical knowledge, and continuously improve the work standards of being scientific and professional. On the other hand, via the combination of a "full-time and part-time" teacher echelon, the counselors get involved in the construction of campus business startup education base and project guidance. This makes colleges and universities available to achieve the normalization and diversification, and ensure the feasibility and effectiveness of innovation and business startup education. In addition, it is also necessary to actively organize counselors to exchange and study with related companies and departments, so that they can understand the market and broaden their knowledge, which, in turn, provides guarantee for innovation and business startup guidance. 


\subsection{Counselors should take the initiative to enhance the comprehensive quality of innovation and business startup}

First, strengthen the concept of learning and actively participate in innovation and business startup education. Counselors should enhance life-long learning awareness, initiatively participate in various innovation and business startup training, learn the latest business startup curriculum system, and obtain business startup tutor qualifications. They should also discuss the innovation and business startup topics, understand the latest concept of innovation and business startup policies, coordinate the time cost at the complex students' management affairs, and strive to take part-time training at enterprises. In this way, they can develop students' innovation and business startup education with their solid theoretical foundation and rich practical experience. Second, counselors should create a positive atmosphere and conduct innovation and business startup education activities aimed at different levels and modules. Combining the needs of students in different grades, they can foster innovative awareness and entrepreneurial interest in primary grades, and launch career development and entrepreneurial practice activities in middle and high grades. With class construction and community activities as the carrier, we can organize innovation and business startup activities in modules, focusing on the cultivation of will and quality of innovation and business startup such as insight, self-thinking, decision-making, organization, influence power, execution, and stress-resisting. Counselors should actively introduce innovation and business startup to students and encourage them to participate in training like KAB and SYB (starting your business) as well, which will improve students' entrepreneurial awareness and enthusiasm, and help clarify entrepreneurial goals.

\section{Conclusion}

Under the background of "mass entrepreneurship and innovation" education concept, counselors are indeed the backbone and tower of strength of college students' entrepreneurial education. The fact that they have face to face contact and exchange with college students makes them the sole and dominant force to effectively conduct college students' innovation and business startup education. It is therefore very necessary to clear the obstacles that prevent college counselors from doing well in innovation and business startup guidance. Several proposals are given below.

First, colleges and universities should lighten counselors' workload, liberating them from complicated business tasks, which will allow them to dedicate more in business startup education and guide the students in their selection of innovative business startup theory courses. Counselors also play an irreplaceable role in organizing innovation and business startup practice activities, cultivating students' interest in innovation and business startup, and fully excavating the entrepreneurial potential of college students.

Second, colleges and universities should make the innovation and business startup education worthwhile by giving affirmation and reward to the counselors' achievements, supporting the counselors spiritually and materially, and fully mobilizing the enthusiasm and creativity of the counselors. Being confident in the process of innovation and business startup education, and making achievements, counselors can effectively serve as mentors and service providers for business startup education. 
Last but surely not least, colleges and universities should strengthen the skill training of counselors in innovation and business startup. This will allow the counselors to enrich their own knowledge by learning the latest policy, to better spread the information and practice psychological guidance. Counselors can also give great innovation and business startup guidance by starting their own businesses, to provide students with practical platforms for entrepreneurial consultation that can also be a strong back up for their future businesses.

\section{Acknowledgements}

This work is supported by Southwest Petroleum University Innovation and Entrepreneurship Fund Project; the grant numbers is SWPUSC16-019.

\section{References}

[1] H.B. Zhu, K. Zhang, U.S.Ogbodo. Review on Innovation and Entrepreneurship Education in Chinese Universities during 2010-2015, EURASIA Journal of Mathematics Science and Technology Education, vol.13 (2017)No.8, p.5939-5948.

[2] H. Gao, Z.W. Qiu, Z.Y. Liu, et al. Research and Practice on College Students' Innovation and Entrepreneurship Education, International Conference of Pioneering Computer Scientists, Engineers and Educators(ICPCSEE, originally ICYCSEE), 2016.No.2, p.14-15.

[3] X.W. Jiang, Y.H. Sun. Study on Constructing an Education Platform for Innovation and Entrepreneurship of University Student, Research Journal of Applied Sciences, Engineering and Technology, vol. 9 (2015) No.10, p.824-829.

[4] Y.Y. Ding. The constraints of innovation and entrepreneurship education for university students, Journal of Interdisciplinary Mathematics, vol. 20 (2017), 1431-1434.

[5] Douglas Henrique Garcia, Andreia Damasio Leles and Regiane Relva Romano. Program Entrepreneurship and Innovation: Education as the Core of Innovation, Advances in The Human Side of Service Engineering, vol. 494 (2017), 235-244. 